\title{
Partial Budget Analysis of Mastitis Control Measures in Villupuram and Namakkal Districts of Tamil Nadu
}

\author{
(R. John Christy ${ }^{1}$ and R. Vijayalakshmi ${ }^{2}$ ) \\ Division of Animal Husbandry, Faculty of Agriculture \\ Annamalai University, Annamalai Nagar -608002India
}

\section{Introduction}

Livestock in general and dairying in particular play a major role in the Indian rural economy. The importance of dairying in India hardly needs emphasizing as this sector is the major source of income for an estimated 27.6 million people.Livestock sector provides employment to many people and nearly 70 per cent of them are women (Subbarama Naidu and Kondaiah, 2004). Smallholder dairy production in India contributes significantly to the income of the poor and middle class urban dwellers, rearing only few cows. Diseases and parasites are serious constraints affecting dairy cattle production in various ways such as reduced growth rate, milk production, fertility and value of hides and mortality causing considerable economic losses to livestock keepers (Chenyambugaet al., 2010).

In dairy practice, disorders of the udder are among the most frequent clinical conditions encountered (Fourichonet al., 2001).Mastitis is an inflammation of the mammary glands of dairy cows accompanied by physical, chemical, pathological and bacteriological changes in milk and glandular tissue (Hurley and Morrin, 1997). It is considered as one of the most costly disease affecting dairy cows. Economic losses due to mastitis are recognized worldwide as a major problem on dairy farms. Reviews of past calculations of the economic losses of clinical mastitis (Schepers and Dijkhuizen, 1991; Halasaet al., 2007) clearly show that mastitis has a great economic impact.

The difficulties encountered in attempts to control mastitis successfully under field conditions reflect both the complex disease etiology and a need to improve the control programs (Slettbakket al., 1995). The assessment of the economic worthiness of a control programme for mastitis has to be supported by a reliable evaluation of the economic losses caused by the disease and the knowledge of the costs of the implementation of that programme (Seegerset al., 2003). Many studies conducted previously to estimate the economic losses due to mastitis in India and abroad were based on the data collected from organized dairy farms having hundreds of animals where as India has about three times as many 'dairy' animals as the USA, the vast majority (over 80 percent) being kept in herds of 2 to 8 animals (Hemmeet al.,2003). Hence, the objective is to study the clinical mastitis control strategies on the data collected from the herds having 2 to 8 animals in the selected area.

\section{Methodology}

Villupuram and Namakkal Districts of Tamil Nadu were randomly selected for the present study. Multistage random sampling technique was used to select the dairy farmers and dairy animals. The Villupuram district comprised 22 blocks of which, three blocks, viz.,Kallakurichi, Thiyagadurgam and Thirukoilur were randomly selected. The Namakkal district comprised 15 blocks of which, three blocks, viz.,Kabilarmalai, Mohanur and Namakkalwere randomly selected. In the next stage, two villages from each selected block were chosen randomly.In total, 1800 farmers having dairy herd size of 2 to 8 were chosen again randomly from the selected blocks, 300 from each block for survey. Among 1800 dairy farmers, 340 dairy farmers experienced mastitis incidence during the study period. Relevant data were collected from the chosen respondents through personal interview using a pre-tested interview schedule. The data were pertaining to the years 2011-12 and 2012-13. Cross checks were made to minimize the errors due to recall bias and also to ensure reliability of the information provided by the respondents. Percentage analysis was employed to analyse the incidence of mastitis. Three sets of different mastitis control measures and their combinations are evaluated with partial budget analysis. First set comprised of practicing a set of control measures such as practising washing of udders before and after milking, teat dipping, cleaning of stalls twice every day, keeping cows standing after milking for at least 30 minutes, fore stripping and lastlymilking the clinically affected cows. Second and third control

\footnotetext{
${ }^{1}$ Assistant Professor in Animal Husbandry, Faculty of Agriculture, Annamalai University, Annamalai Nagar, Pin 608002

${ }^{2}$ AssociateProfessor and Head, Division of Animal Husbandry, Faculty of Agriculture, Annamalai University, Annamalai Nagar, Pin 608002
} 
measures adopted are being dry cow therapy and culling of chronic cases, respectively. Cost and return data collected from the study area are used to construct partial budget model in Microsoft Excel 2007.

\section{Results and Discussion}

Practising measures (Table I) such as washing udder before and after milking, teat dipping, cleaning of stalls twice every day, keeping cows standing after milking for at least 30 minutes, fore stripping and milking clinical cases last, treating clinical cases, culling chronic cases and dry cow therapy were found to be the different mastitis control measures in the study area and many researchers found these measures were highly useful in the control of mastitis.

The effect of mastitis control measures practiced on the incidence is presented in Table 2. The incidence of mastitis was very high (95.73 per cent) among the animals where none of the control measures were adopted. Implementation ofpractising first set of control measures that include washing of udder before and after milking, teat dipping, cleaning of stalls twice every day, keeping cows standing after milking for at least 30 minutes, fore stripping and milking clinical cases last resulted in the mastitis incidence of mere 1.36 per cent. Practising of dry cow therapy (Measure II) alone resulted in the mastitis incidence of 33.33 per cent. In the study area, none of the farmers implemented culling of chronically affected animals (Measure III) as a sole mastitis control strategy. The combination of control measures I and II were found to be highly effective with zero mastitis incidence. Adoption of all the three measures (Combining measures I, II and III) also resulted in zero mastitis incidence. Implementation of dry cow therapy along with culling of chronic clinical cases (Combining measures II and III) apparently had no effect on the control of mastitis as all the animals were infected with mastitis.

For example, Mdegelaet al. (2009) advocated the use of udder disinfectants and improved milking hygiene as intervention strategies to control mastitis on the smallholder dairy farms in Tanzania. Deb et al. (2013) added that improvement of milking hygiene, implementation of post-milking teat disinfection and regular control of the milking equipments were among the important general measures to prevent new cases of mastitis. Robert et al. (2008) and Runcimanet al. (2010) encouraged the use of selective dry cow antibiotic therapy towards the prevention of new intra mammary infections.

Cost effectiveness of three different sets of mastitis control measures practised in the study area were estimated based on an economics module which rely on the principles of partial budgeting in which the economic consequences of a specific change were quantified. First set of control measures comprised a combination of practising washing of udders before and after milking, teat dipping, stalls are cleaned twice every day, keeping cows standing after milking for at least 30 minutes, fore stripping and milking clinical cases last. Second control measure evaluated was being dry cow therapy) which include the intra mammary infusion of antibiotics immediately after the final milking of the lactation period and intramuscular injection of enrofloxacin (Baytril, 10\% inj. sol. (O), Bayer) at a dose of $2.5 \mathrm{mg} / \mathrm{kg}$ to all cows. Third control measure evaluated was culling of chronic cases. Different combinations of above mentioned control measures as practised in the study area are also evaluated.

Partial budget analysis revealed that first set of control measures (Measure I) resulted in a highest net returns of Rs, 1666.96 and implementation of dry cow therapy ensued a lesser positive return of Rs. 1115.83 which was largely due to higher drug cost, veterinarian's fees when compared to first set of control measures. Further, implementation of culling of chronic mastitic animals would led to a net negative return of Rs, 2632.97. Though culling was considered as an effective mastitis control measure, the analysis found it as economically infeasible. Further, partial budget analysis revealed that implementation of control measure I with dry cow therapy (Combination of measures I and II) resulted with a net returns of Rs, 1210.39. All other combinations of control measures (Measure III, II \& III and I,II \& III) resulted in only negative returns.

Neave et al. (1969) stated that the complete prevention of the transfer of pathogens causing mastitis from cow to cow had not been found possible, even with a comprehensive hygiene system. Nevertheless, hygiene systems designed to prevent the transfer of pathogens and more particularly to eliminate residual contamination at the completion of milking had been shown to reduce the number of new infections by about half. The combination of such hygiene systems with effective antibiotic therapy, which reduced the duration of infection, generally resulted in a decrease of more than 50 per cent in the incidence of infection within a year.

Beck et al. (1992) stated that the farms that have followed the recommended control procedures have reduced the average annual number of cases of clinical mastitis from 135 to 40 cases/100 cows each year, while the quarters remaining uninfected for a whole year has increased from 65 to 80 per cent of the total quarters. The costs of the main control procedures (Eg. £8-60/cow for dry-cow therapy and teat dipping or spraying) are broadly covered by the reduction in clinical mastitis, leaving the benefits of reduced subclinical infection (e.g. $£ 3810$ for a 100 cow herd unconstrained by quota and achieving the average reduction in infection) as a substantial bonus. McDougall et al. (2009) reported that mastitis was a multifactorial disease, hence control required an understanding of the risk factors before effective interventions can be defined and potential control 
strategies included improved environmental and animal hygiene, application of internal and external teat sealants, prepartum application of teat antiseptics, prepartum milking and control of horn fly in environments where it acts as vector.

Firat (1993) and Thirunavukkarasu (1996) stated that the control of mastitis might be possible through controlling environmental factors predisposing mastitis and thereby masking the animal factors influencing udder infection. Sandhol et al.(1990) showed that mere antibiotic usage had not resulted in complete control of mastitis. The U.S. National Mastitis Council and most Canadian Dairy Extension Programmes recommended a mastitis control programme consisting of hygienic washing and drying of udders before milking,teat dipping after milking, antibiotic therapy at drying off, culling cows with chronic mastitis and milking the infected cows lastly (Thirunavukkarasu, 1996). As none of the selected animal owners had or needed milking machine, there is no point in insisting on regular milking machine maintenance in rural small farmers.

\section{Conclusion}

The results of the study clearly showed that measures such as practising washing of udders before and after milking, teat dipping, stalls are cleaned twice every day, keeping cows standing after milking for at least 30 minutes, fore stripping, milking clinical cases lastly and dry cow therapy appears to be most appropriate methods of controlling mastitis in rural areas, which is still characterised by large number of small dairy units managed with family labour. The focus of mastitis control efforts should be on sanitising the general environment and preventing the contamination of teat pore during the period in which the streak canal remains open after milking as stated by Cullor (1993) and Thirunavukkarasu (1996). Well-knit extension programme about disease awareness, giving adequate emphasis to management and control measures is to be developed for education at farmers' level as udder health, hygiene and nutrition play an important role in the control of mastitis. The best and cost effective practices for reducing the incidence of mastitis like teat dip after milking, not allowing the cows to sit for 30 minutes after milking, emphasizing clean housing and milking hygiene should be propagated widely among the dairy farming community through appropriate channel.

\section{Reference}

[1]. Beck, H.S., W.S. Wise and F.H. Dodd (1992). Cost benefit analysis of bovine mastitis in the UK. Journal of Dairy Research., 59(4):449-460

[2]. Chenyambuga, S.W., C.Waiswa, M.Saimo, P.Ngumi and P.S.Gwakisa (2010). Knowledge and perceptions of traditional livestock keepers on tick-borne diseases and sero-prevalence of Theileriaparva around Lake Victoria Basin. Livestock Research for Rural Development.,22: 7

[3]. Cullor, J.S. (1993). The control, treatment and prevention of the various types of bovine mastitis. Veterinary Medicine.,18: 571-579.

[4]. Deb, R., A.Kumar, S.Chakraborty, A.K.Verma, R.Tiwari,K.Dhama, U.Singh, and S. Kumar(2013). Trends in diagnosis and control of bovine mastitis: a review. Pakistan Journal of Biological Science., 16(23):1653-61.

[5]. Firat, M.Z. (1993). Susceptibility of clinical mastitis in successive lactations. Livestock Production Science., 34(1 \& 2) : 175-180.

[6]. Fourichon, C., H.Seegers,F.Beaudeau, L. VerfailleandN.Bareille (2001).Health-control costs in dairy farming systems in western France. Livestock Production Science.,68:141-156.

[7]. Halasa, T., K.Huijps, O. OsterasandH.Hogeveen (2007). Economic effects of bovine mastitis and mastitis management: a review. Veterinary Quarterly.,29(1): 18-31.

[8]. Hurley, L. and E.Morrin (1997). Introduction to mastitis. In: Lactation by Hurley (Ed). University of Illinois, Urbana, USA.

[9]. McDougall, S., K.I. Parker, C. Heuer, C.W.R. Compton (2009). A review of prevention and control of heifer mastitis via nonantibiotic strategies. Veterinary Microbiology.,134 (1-2): 177-185

[10]. Mdegela, R,H., R. Ryoba,E.D .Karimuribo, E.J.Phiri, T.Løken, O.Reksen, E .Mtengeti and N.A.Urio. (2009). Prevalence of clinical and subclinical mastitis and quality of milk on smallholder dairy farms in Tanzania. Journal of the South African Veterinary Association.,. 80(3):163-8.

[11]. Neave,F.K. , F.H. Dodd, R.G. Kingwill and D.R. Westgarth (1969). Control of mastitis in the dairy herd by hygiene and management.Journal of Dairy Science., 52 (5):696-707

[12]. Robert, A. , P. Roussel, N. Bareille, D. Ribaud, F. Sérieys, V. Heuchel and H. Seegers. (2008). Risk factors for new intramammary infections during the dry period in untreated dairy cows from herds using selective dry cow therapy. Animal.,2 (02):247-254

[13]. Runciman,D.J., J. Malmo and M. Deighton (2010). The use of an internal teat sealant in combination with Cloxacillin dry cow therapy for the prevention of clinical and subclinical mastitis in seasonal calving dairy cows. Journal of Dairy Science.,93(10) :4582-4591

[14]. Sandhol, M., M.L. Kaartinen and S. Pyorala (1990). Bovine mastitis - why does antibiotic therapy does not always work: An overview. Journal of Veterinary Pharmacology Theory., $13: 248-260$.

[15]. Schepers, J. A., and A. A. Dijkhuizen(1991). The economics of mastitis and mastitis control in dairy herds: a critical analysis of estimates published since 1970. Preventive Veterinary Medicine.,10:213-224.

[16]. Seegers, H., C.FourichonandBeaudeau, F. (2003). Production effects related to mastitis and mastitis economics in dairy cattle herds. Veterinary Research., 34(5): 475-491.

[17]. Slettbakk, T. , A. Jarstad ,B.Thomas,Farver and J.C. Holmes(1995). Impact of milking characteristics and morphology udder and teats on clinical mastitis in first- and second-lactation Norwegian cattle.Preventive Veterinary Medicine., 24: 235-244

[18]. Subbarama Naidu, A. and N. Kondaiah (2004). Livestock production and post production systems - Need for a pragmatic approach. Indian Journal of Agricultural Marketting., 18: 91-105.

[19]. Thirunavukkarasu, M. (1996). Economic analysis of Mastitis in Dairy Farms, Ph.D. Thesis, Tamil Nadu Veterinary and Animal Sciences University. 
Table 1. Mastitis control measures practiced in the study area

\begin{tabular}{|l|l|}
\hline S. No & \multicolumn{1}{|c|}{ Control measures } \\
\hline 1 & Washing udders before and after milking \\
\hline 2 & Teat dipping \\
\hline 3 & Stalls are cleaned twice every day \\
\hline 4 & Keep cows standing after milking for at least 30 minutes \\
\hline 5 & Fore stripping \\
\hline 6 & Milking clinical cases last \\
\hline 7 & Treating clinical cases \\
\hline 9 & Culling chronic cases \\
\hline
\end{tabular}

Table 2 Relationship between mastitis control measures practiced and the incidence of mastitis

\begin{tabular}{|l|c|c|c|}
\hline \multicolumn{1}{|c|}{ control measures practiced } & Number of animals & $\begin{array}{c}\text { Number of affected } \\
\text { animals }\end{array}$ & Per cent affected \\
\hline Measure I* & 1098 & 15 & 1.36 \\
\hline Dry cow therapy (Measure II) & 15 & 5 & 33.33 \\
\hline $\begin{array}{l}\text { Culling of chronic cases } \\
\text { Measure III) }\end{array}$ & 0 & 0 & 0 \\
\hline $\begin{array}{l}\text { Both Measure I and II } \\
\text { oombined }\end{array}$ & 347 & 6 & 100 \\
\hline $\begin{array}{l}\text { Both Measure II and III } \\
\text { combined }\end{array}$ & 6 & 0 & 0 \\
\hline $\begin{array}{l}\text { Measure I, II and III combined } \\
\text { None }\end{array}$ & 628 & 314 & 95.73 \\
\hline Total & 1800 & 340 & 0 \\
\hline
\end{tabular}

* Measure I Practising washing of udder before and after milking, teat dipping, cleaning of stalls d twice every day, keeping cows standing after milking for at least 30 minutes, fore stripping and milking clinical cases last

Table 3 Partial budget model for mastitis control measures(in rupees)

\begin{tabular}{|l|r|r|r|r|r|}
\hline Control Measures/ Cost & Measure I* & $\begin{array}{l}\text { Dry cow } \\
\text { therapy } \\
\text { (Measure II) }\end{array}$ & $\begin{array}{l}\text { Culling of } \\
\text { chronic cases } \\
\text { (Measure III) }\end{array}$ & $\begin{array}{l}\text { Both } \\
\text { Measure I } \\
\text { and II } \\
\text { combined }\end{array}$ & $\begin{array}{l}\text { Both } \\
\text { Measure II } \\
\text { and III } \\
\text { combined }\end{array}$ \\
\hline Additional returns (A) & 1229.09 & 1229.09 & 0 & 1246.8 & 0 \\
III combined \\
\hline Reduced costs (B)
\end{tabular}

* Practising measures such as washing udders before and after milking, teat dipping, stalls are cleaned twice every day, keeping cows standing after milking for at least 30 minutes, fore stripping and milking clinical cases last 